\title{
Various Temperature of Vacuum and Conventional Roasting on Color Alteration and Polyphenols Content of Cocoa Powder
}

\author{
Tamrin $^{1}$, Harijono ${ }^{2}$, Sudarminto Setyo Yuwono ${ }^{2}$, Teti Estiasih ${ }^{2}$ and Umar Santoso ${ }^{3}$ \\ 1. Food Science and Technology Department, Agriculture Faculty, Haluoleo University, Kendari-Southeast, Sulawesi 93231, \\ Indonesia \\ 2. Food and Agricultural Technology Department, Agricultural Technology Faculty, Brawijaya University, Malang 65145, East \\ Java-Indonesia
}

3. Agricultural and Food Technology Department, Agricultural Technology Faculty, Gadjah Mada University, Yogyakarta 55281 Indonesia

Received: August 22, 2012 / Published: November 20, 2012.

\begin{abstract}
This study has the objective to found out the temperature and raosting time of cocoa powder in order to gain color, aroma and taste favored by the panelist and has high polyphenol content. The roasting time in this research has been determined 35 min, and roasting temperature of $80,90,100,110,120,130,140$ and $150{ }^{\circ} \mathrm{C}$ with vacuum and conventional system. From those temperatures ranges, we would take the three best levels according to organoleptic test result. The three selected temperatures would be tested for changing in polyphenol content during roasting process. Color alteration would be physically analyzed using color reader (PCE-RGB). However, phenol total content was analyzed using colorimetric method of Folin-Ciocalteu. Result of this study showed that color alteration percentage (RGB model analysis) during conventional roasting is higher (43\%) compared with vacuum roasting system (2\%). Subsequently, organoleptic test result showed that from roasting temperatures between $80^{\circ} \mathrm{C}$ and $150{ }^{\circ} \mathrm{C}$, cocoa powder favored by the panelist were those that was treated in temperature $100{ }^{\circ} \mathrm{C}, 110{ }^{\circ} \mathrm{C}$ and $120{ }^{\circ} \mathrm{C}$. Other results indicated that vacuum roasting implementation could increase polyphenol content. While vacuum roasting of $60.8 \mathrm{~cm} \mathrm{Hg}$ in $120{ }^{\circ} \mathrm{C}$ with roasting time of $25 \mathrm{~min}$ has obtained $10.57 \%$ total phenolic, or increasing as much as $1.22 \%$.
\end{abstract}

Key words: Vacuum, roasting, cocoa powder, polyphenol.

\section{Introduction}

Roasting is part of cocoa beans processing stage that could highly determine its final products (either finished product or semi-finished product). Roasting those cocoa beans is mainly to remove undesirable compound with low boiling level point (such as acetate acid), taste formation, color and aroma of chocolate. It also lowered water content, killing microbes and inflating the seed coat to facilitate peeling and grinding $[1,2]$.

Corresponding author: Tamrin, M.Sc., research field: food technology. E-mail: tamrinkendari@yahoo.co.id.
Cocoa beans roasting process could be done using different temperature and heating duration in accord with final product to be produced. Low degree roasting was done in $110-115{ }^{\circ} \mathrm{C}$ for $60 \mathrm{~min}$ to produce chocolate fat and chocolate sweets product. Medium degree roasting was done in $140{ }^{\circ} \mathrm{C}$ for $35-40 \mathrm{~min}$ to produce cocoa powder, chocolate pasta and chocolate bars. High degree roasting was done in $200{ }^{\circ} \mathrm{C}$ for 15-20 min to produce black chocolate pasta [3].

Those ranges of temperature were influencing polyphenol content of cocoa beans. Polyphenol in cocoa beans is very important particularly concerning option in taste, color and aroma development, or as 
functional food (as antioxidant). Some of the previous studies have showed that polyphenol mostly contained in cocoa is flavan-3-ols (monomer epicatechin and catechin which also a constituent of procyanidin) $[4,5]$. Cocoa beans also contain small amounts of anthocyanins (mainly cyaniding glycosides) and flavonols (quercetin glycosides). Polyphenol content in cocoa powder reported in the literature is highly varying with values ranging from 3.3-65 $\mathrm{mg} / \mathrm{g}$ or $1.7-36.5 \mathrm{mg} / \mathrm{g}$ total polyphenol in dark chocolate [6].

Unprocessed cocoa beans contained polyphenol about $15 \%$ from its dry weight, and about $60 \%$ of those polyphenols were present in the form of procyanidins, mostly (-) epicatechin (EC) and catechin. Although some polyphenol is lost during fermentation process, cocoa powder still contained about $1 \%-2 \%$ EC and $(+)$ catechin according to its weight [7]. It showed that during cocoa beans processing to become cocoa powder it has lost its catechin content above $10 \%$.

Cocoa beans roasting process was commonly done by conventional heating. Roasting container used in this process is not vacuum thus there are free oxygen in roasting atmosphere suggested that during cocoa beans roasting using EGM (electromagnetic waves) and conventional, polyphenol content has become smaller. This was assumed to happen because of polyphenol oxidation in the roasting chamber accelerated by temperature and roasting time [8].

Based on the above description, therefore, oxygen in roasting chamber need to be minimized through vacuum roasting system. This system is likely to reduce oxidation process, thus polyphenol decrease could be reduced.

\section{Materials and Methods}

Dry cocoa beans were taken from estate of people in District Lasusua, Kabupaten North Kolaka, Southeast Sulawesi. Chemicals involved include: methanol, ethanol, distilled water (for extraction of cocoa powder), materials for total phenol analysis (such as ethanol, sodium carbonate, and Folin-Ciocalteu reagents) (Sigma Chemical Co., St. Louis).

Tools used for roasting treatment are fryer water jet vacuum system that has been modified. As for cocoa powder processing would be using hydraulic press with 50 ton pressure capacity, wheat grinder, 80 mesh sieve and several supporting tools (such as packaging equipment etc.). Extraction tools would include, shaker waterbath, evaporator used to dry liquid extract in the form of rotary vacuum evaporator HEIDOLPH type Laborota 4000 Vacuum-Controller VC. 2 and UV Vis Spectrophotometer (Shimadzu, UV-1650 PC).

\subsection{Roasting Processing}

Initial sampling activities of cocoa beans in District Lasusua are collecting dried cocoa beans in the form of ready sale. Next activity is sample preparation by processing dried cocoa beans into powder. This cocoa powder would be treated with roasting treatment (vacuum and conventional).

Cocoa roasting might be done in the form of beans (bean roasting), nib cocoa (nib roasting) and crushed seeds (mass roasting). This study is using mass roasting principle, which is by roasting cocoa powder. This powder is the result from nib cocoa which has been through compression process to remove its fat, and then ground to obtain minimum 80 mesh particle size. Next would be roasting process using vacuum and conventional condition in temperature 80, 90, 100, 110, $120^{\circ} \mathrm{C}, 130,140$ and $150{ }^{\circ} \mathrm{C}$. From those range, we would take three roasting temperature based on organoleptic test result. 27 semi-trained panelist were used, scale value used in this test is 1-5 (really dislike, really like). Data obtained would be analyzed using variance analysis and Duncan multiple range test using SAS statistic software.

\subsection{Cocoa Powder Making Procedure}

Processing cocoa beans sample into cocoa powder is following Minifie and Wahyudi et al. [2, 9] procedures 
with a bit modification that is dried and sorted cocoa beans would be roasted in $120{ }^{\circ} \mathrm{C}$ for $25 \mathrm{~min}$ to facilitate seed coat peeling. Nib cocoa obtained would be heated in $80^{\circ} \mathrm{C}$ for 10 min before pressed to remove its fat. Nib cocoa after pressed would then be grounded to obtain cocoa powder.

\subsection{Cocoa Powder Preparation for Polyphenol Extraction}

Extraction was done using modified method from Othman et al. and Ruzaidi et al. [10, 11]. Cocoa powder macerated using $70 \%$ alcohol (1 g cocoa powder was dissolved in $25 \mathrm{~mL}$ solvent (70\% ethanol) for $120 \mathrm{~min}$ in $50^{\circ} \mathrm{C}$ using orbital shaker. Subsequently, it is cooled in room temperature and then filtered using Whatman paper No. 1. Filtered results should be extracted twice using the same solvent, and then evaporated using rotary vacuum evaporator to gain dried extract of cocoa powder.

\subsection{Total Phenol Content Analysis}

Total phenol content analysis toward extract cocoa powder was tested using colorimetric method of Folin-Ciocalteu [10, 12, 13]. Standard curve making was done by giving $0.5 \mathrm{~mL}$ Gallat acid solution in deionized water with series concentration of gallat acid standard ( 0 , 40, 80, 120, 160, and $200 \mathrm{ppm}$ ) inside reaction tube and

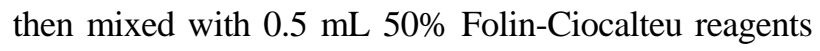
(Sigma Chemical Co., St. Louis, MO., USA) and $7.5 \mathrm{~mL}$ deionized water. This mixture was left in room temperature for $10 \mathrm{~min}$ and then added with $1.5 \mathrm{~mL} \mathrm{2 \%}$ sodium carbonate (w/v). This mixture would then heated in $40{ }^{\circ} \mathrm{C}$ within waterbath for $20 \mathrm{~min}$, and should be cooled immediately. Next, absorbance was measured in $755 \mathrm{~nm}$.

Absorbance result as the concentration function of gallat acid content was plotted in graph and was being used as gallat acid standard curve. Extract sample testing was conducted as before and related with this standard curve equation, therefore total phenol concentration (gallic acid) within samples was known in the form of percentage (\%) phenol per samples weight [12].

\subsection{Analysis and Data Interpretation}

All data obtained from each study's stage was tabulated and analyzed according to the needs and final objective of each stage, using variance analysis (ANOVA). Differences in result would be tested using Duncan Multiple Range Test (DMRT) in 5\% level. Regression test was done particularly to see the interaction of treatment and to determine optimal point of each factor.

\section{Results and Discussion}

3.1 Effect of Temperature and Vacuum Raosting Time against Physical and Organoleptic Characteristic of Cocoa Powder

3.1.1 Color Characteristic of Cocoa Powder according to RGB Model

Effect of temperature $\left(80{ }^{\circ} \mathrm{C}-150{ }^{\circ} \mathrm{C}\right)$ and roasting time of 35 min (vacuum and conventional) in cocoa powder toward color alteration, was analyzed using color analyzer (chromameter PCE-RGB) for quantification. Meursing [14] describes that color quantification was developed from the basic idea that color is resulted by a mixture of three basic colors red, green and blue or RGB. These three basic colors were in accordance with cones type of eye retina.

Color quantification data obtained from this method would be tabulated and subjected to regression test. This analysis was intended to see the closeness of relationship between temperature and roasting time (vacuum and conventional) toward color alteration of cocoa powder. Based on the calculation result, it is known that regression equation model according to each color feature was as shown in Table 1.

Based on Table 1, it is known that during vacuum roasting, the determination coefficient value $\left(R^{2}\right)$ for red (R) is higher than green (G) and blue (B). This illustrates that color alteration during vacuum roasting is determined by alteration in red color feature. However, if we see determination coefficient value $(0.0200)$, we can see that the effect of the red color is only $2 \%$, thus 
Table 1 Regression model of color alteration in cocoa powder at various roasting temperature in vacuum $60.8 \mathrm{~cm} \mathrm{Hg}$ and conventional condition.

\begin{tabular}{llll}
\hline \multirow{2}{*}{ Treatment } & $\begin{array}{l}\text { Regression model according to the Regression model according to the Regression model according to the } \\
\text { color red (Red) "R" }\end{array}$ & $\begin{array}{l}\text { color green (Green) “G” } \\
\text { color blue (Blue) "B” }\end{array}$ \\
\hline \multirow{2}{*}{ Vacuum 60.8 cm Hg } & $Y=0.0714+257.79 x$ & $Y=0.0190+128.309 x$ & $Y=0.0119+124.88 x$ \\
& $R^{2}=0.0200$ & $R^{2}=0,0058$ & $R^{2}=0.0030$ \\
\hline \multirow{2}{*}{ Conventional } & $Y=407.036-1.003 x$ & $Y=201.345-0.509 x$ & $Y=192.119-0.486 x$ \\
& $R^{2}=0.4027$ & $R^{2}=0.4273$ & $R^{2}=0.4283$ \\
\hline
\end{tabular}

we could say that effect of roasting temperature in vacuum condition toward color alteration of cocoa powder is very low. Meursing [14] describes that in cocoa powder, low hue $(\mathrm{H})$ value indicated by red color and high $\mathrm{H}$ value indicated by brown color. Hue is stating the actual color, used to distinguish color regarding determination of redness, greenness and other color components of light.

Different events according to Table 1 is showed by determination coefficient value $\left(R^{2}\right)$ of conventional roasting, in which red color $(0.40)$ is smaller than green and blue color (0.43). This showed that effect of roasting temperature in conventional condition toward cocoa powder's color alteration is more determined by green and blue color (about 43\%). This condition can clarify that color alteration percentage during conventional roasting (43\%) is higher compared with vacuum system (2\%). Differences in color alteration could be seen in Figs. 1-3.

Based on Figs. 1-3, it is known that during the beginning of roasting (temperature $80{ }^{\circ} \mathrm{C}-100{ }^{\circ} \mathrm{C}$ ), there were decline in RGB color feature. This decline is occurring at two type of roasting, however, in vacuum roasting this value is higher. Those three figures also describes that in $110{ }^{\circ} \mathrm{C}$ of roasting temperature there are RGB increase both in vacuum and conventional condition. But in conventional roasting, RGB increase in $110{ }^{\circ} \mathrm{C}$ is higher than in vacuum condition. This phenomenon describes that other than temperature, condition of vacuum pressure within roasting chamber could also affecting color alteration of cocoa powder. This might related with low oxygen available within vacuum roasting chamber which eventually affecting oxidation process of color precursor compounds (such as polyphenol/flavonoid) during roasting.

Krysiak [15] describes that oxidation and polyphenol polymerization, protein degradation, Mailard reaction and starch dextrinization that produces brown pigment is an identifying mark of cocoa roasting. His study showed that color alteration in roasted cocoa beans (conventional) in $110^{\circ} \mathrm{C}, 135^{\circ} \mathrm{C}$ and $150{ }^{\circ} \mathrm{C}$ is affecting the brown pigment. Davey [16] reported that heating process affecting phytochemicals (polyphenol etc.) damage is combination of components migration that contribute to loss or damage by variety chemical reactions involving enzymes, light and oxygen.

Zainol et al. [17] reported a study in effect of drying method toward flavonoid reduction which found out that freeze drying would produce lower reduction compared with vacuum drying $\left(45^{\circ} \mathrm{C}\right.$ for $5 \mathrm{~h}$ in vacuum $15 \mathrm{psi}$ ) and air drying $\left(45^{\circ} \mathrm{C}\right.$ for $48 \mathrm{~h}$ ). However, maintained active compound is quite high in vacuum drying.

3.1.2 Organoleptic Test of Taste, Aroma, and Color of Cocoa Powder

Improving color and taste of cocoa powder could be done by implementing alkalization step during processing. Wahyudi et al. [2] described that alkalization was done to improve dispersibility/suspension capacity of cocoa powder in water and to improve its color and flavor. Some alkali materials to be used are potassium carbonate, natrium carbonate, potassium/natrium bicarbonate, potassium/natrium hydroxide, ammonium carbonate, or ammonium hydroxide. However, in this study, alkalization step was not used because of two considerations: first, to reduce contamination of synthetic chemical substance with cocoa powder, and 


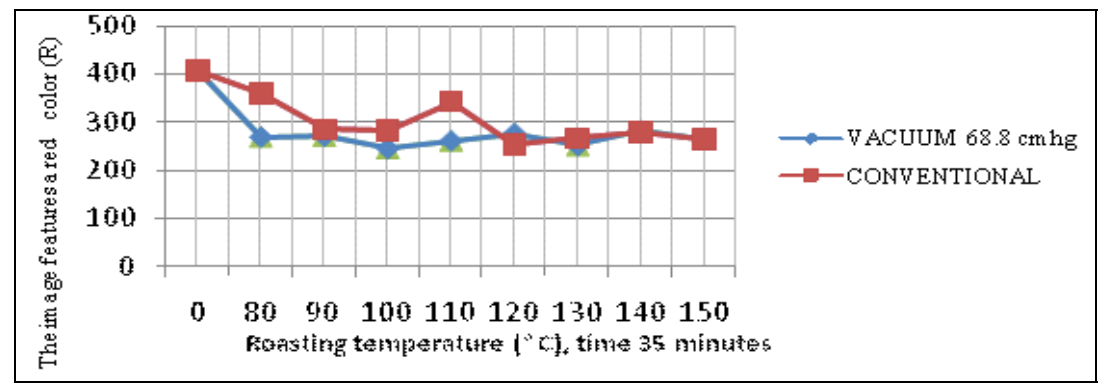

Fig. 1 Effect of temperature and vacuum on the image roasting Red (R) cocoa powder using the RGB of color analyzer.

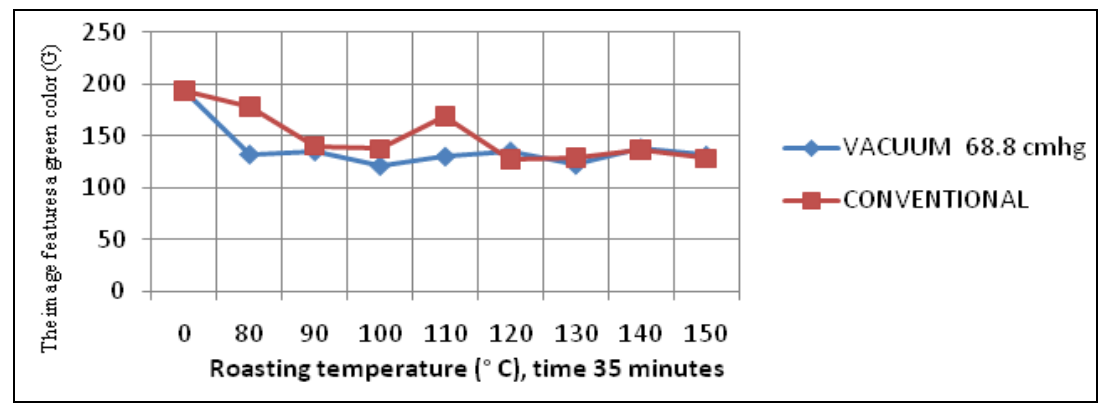

Fig. 2 Effect of temperature and vacuum on the image roasting Green (G) cocoa powder using the RGB of color analyzer.

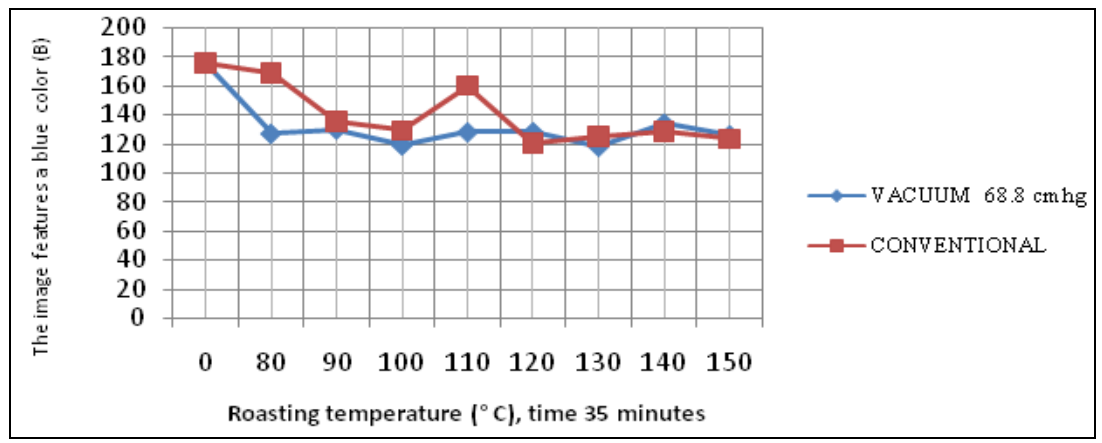

Fig. 3 Effect of temperature and vacuum on the image roasting Blue (B) cocoa powder using the RGB of color analyzer.

second is related with decreased content of antioxidant. Ziegleder and Biehl [18] described that alkalization process could reduce antioxidant content.

Variance analysis result showed that roasting time of 35 min in vacuum and conventional condition with various temperature levels has significant effect toward taste, aroma and color of cocoa powder. Average of the panelist expressed a bit like-like (score 2.9-3.4) in tested cocoa powder. Furthermore, to distinguish between each treatment we conduct DMRT test (Duncan's Multiple Range Test) which results in Tables 2-4.

Table 2 shows that the treatment vacuum roasting between temperatures of $150,140,130,110,100{ }^{\circ} \mathrm{C}$ were not significantly different to the taste, as well as the temperature of $140,130,110$, and $100{ }^{\circ} \mathrm{C}$. But the
Table 2 Effect of roasting temperature in vacuum and conventional condition ( $35 \mathrm{~min}$ ) on taste of cocoa powder.

\begin{tabular}{lll}
\hline \multirow{2}{*}{ Temperature $\left({ }^{\circ} \mathrm{C}\right)$} & \multicolumn{2}{c}{ Flavor score } \\
\cline { 2 - 3 } & Vacuum $(60.8 \mathrm{~cm} \mathrm{Hg})$ & Conventional \\
\hline 150 & $3.25 \mathrm{a}$ & $3.22 \mathrm{ab}$ \\
140 & $3.14 \mathrm{bc}$ & $3.11 \mathrm{bc}$ \\
130 & $3.18 \mathrm{bc}$ & $3.00 \mathrm{bc}$ \\
120 & $3.18 \mathrm{bc}$ & $3.03 \mathrm{bc}$ \\
110 & $2.77 \mathrm{bc}$ & $2.88 \mathrm{bc}$ \\
100 & $3.03 \mathrm{bc}$ & $2.59 \mathrm{~cd}$ \\
\hline
\end{tabular}

The same letter indicates not significantly different (alpha 0.05).

temperature of $150{ }^{\circ} \mathrm{C}$ and $120{ }^{\circ} \mathrm{C}$ significantly different. Whereas in conventional roasting between the temperature of 150 and $110{ }^{\circ} \mathrm{C}$ were not significantly different, so the temperature of 140 and $100{ }^{\circ} \mathrm{C}$. while a temperature of 150 and $100^{\circ} \mathrm{C}$ 

Alteration and Polyphenols Content of Cocoa Powder

Table 3 Effect of roasting temperature in vacuum and conventional condition (35 min) on aroma of cocoa powder.

\begin{tabular}{lll}
\hline \multirow{2}{*}{ Temperature $\left({ }^{\circ} \mathrm{C}\right)$} & Aroma score \\
\cline { 2 - 3 } & Vakum $(60.8 \mathrm{~cm} \mathrm{Hg})$ & Conventional \\
\hline 150 & $3.70 \mathrm{ab}$ & $3.77 \mathrm{ab}$ \\
140 & $3.74 \mathrm{ab}$ & $3.96 \mathrm{a}$ \\
130 & $3.44 \mathrm{bc}$ & $3.48 \mathrm{bc}$ \\
120 & $3.18 \mathrm{c}$ & $3.62 \mathrm{bc}$ \\
110 & $3.00 \mathrm{c}$ & $3.14 \mathrm{c}$ \\
100 & $3.18 \mathrm{c}$ & $3.55 \mathrm{ab}$ \\
\hline
\end{tabular}

The same letter indicates not significantly different (alpha 0.05).

Table 4 Effect of roasting temperature in vacuum and conventional condition ( $35 \mathrm{~min}$ ) on color of cocoa powder.

\begin{tabular}{lll}
\hline \multirow{2}{*}{ Temperature $\left({ }^{\circ} \mathrm{C}\right)$} & Color score & \\
\cline { 2 - 3 } & Vacuum $(60.8 \mathrm{~cm} \mathrm{Hg})$ & Conventional \\
\hline 150 & $3.37 \mathrm{ab}$ & $3.37 \mathrm{ab}$ \\
140 & $3.51 \mathrm{a}$ & $3.22 \mathrm{ab}$ \\
130 & $3.25 \mathrm{ab}$ & $3.18 \mathrm{bc}$ \\
120 & $2.96 \mathrm{c}$ & $3.14 \mathrm{bc}$ \\
110 & $2.77 \mathrm{~d}$ & $2.66 \mathrm{~d}$ \\
100 & $3.40 \mathrm{ab}$ & $2.92 \mathrm{c}$ \\
\hline
\end{tabular}

The same letter indicates not significantly different (alpha 0.05).

significantly different.

Table 3 shows that the conventional roasting treatment between temperature, 150, 140, 130, 120, and $100{ }^{\circ} \mathrm{C}$ and not significantly different from the aroma, as well as between $130,120,110$ and $100{ }^{\circ} \mathrm{C}$. But the 140 and $150{ }^{\circ} \mathrm{C}$ treatment significantly different from the $110{ }^{\circ} \mathrm{C}$. While vacuum roasting between temperatures of 140,150 and $130^{\circ} \mathrm{C}$ were not significantly different, as well as the temperature of $130,120,110$ and $100{ }^{\circ} \mathrm{C}$. But the temperature of 150 and $140{ }^{\circ} \mathrm{C}$ significantly different temperatures of 120 , 110 and $100{ }^{\circ} \mathrm{C}$.

Table 4 shows that the vacuum roasting between temperatures of $150,140,130$, and $100{ }^{\circ} \mathrm{C}$ were not significantly different to the color, as well as the temperature of $150,130,120$ and $100{ }^{\circ} \mathrm{C}$ as well as the temperature of 130,120 and $110{ }^{\circ} \mathrm{C}$. But the temperature of $140 \quad{ }^{\circ} \mathrm{C}$ significantly different temperature of 120 and $110{ }^{\circ} \mathrm{C}$. Whereas in conventional roasting between $150-120$ and $100{ }^{\circ} \mathrm{C}$ temperature was not significantly different, also between $120-100{ }^{\circ} \mathrm{C}$ temperature. But the $150-130{ }^{\circ} \mathrm{C}$ temperature with a temperature of $110^{\circ} \mathrm{C}$.

Based on Tables 2-4, it is known that temperature below $100{ }^{\circ} \mathrm{C}$ gave low response toward aroma and taste. While roasting temperature of $100^{\circ} \mathrm{C}-150{ }^{\circ} \mathrm{C}$ for aroma and flavor of cocoa powder is a bit like both in vacuum and conventional condition. This condition describes that it is possible if aroma and taste constituent have not yet formed optimally during those temperature ranges. However, cocoa powder roasted in those temperature ranges has been acceptable by consumers.

3.1.3 Three Selected Roasting Temperature for Polyphenol Content Test

Based on the previous analysis results, it is known that roasting temperature ranges from $100-150{ }^{\circ} \mathrm{C}$ for aroma and taste of cocoa powder is a bit like both in vacuum and conventional condition. While for color, panelist likes cocoa powder with roasting temperature 100, 130 and $150{ }^{\circ} \mathrm{C}$ in vacuum and $150{ }^{\circ} \mathrm{C}$ in conventional condition. Thus, it is known that roasting cocoa powder in those ranges has been acceptable by consumers.

Misnawi et al. [19] describe that the forming compound for chocolate typical aroma is significantly increasing during roasting of $35 \mathrm{~min}$ until $65 \mathrm{~min}$ in $140{ }^{\circ} \mathrm{C}$. In temperature of $120{ }^{\circ} \mathrm{C}$, there was increasing polyphenol concentration. Supriyanto et al. [20] suggested that during roasting in $140{ }^{\circ} \mathrm{C}$ for 40 min there were decrease in antioxidant activity of cocoa powder with fix speed of $0.039 \%$ per min. Kofink et al. [21] suggested that roasting temperature (120-160 ${ }^{\circ} \mathrm{C}$, for 2.5 hours) could cause catechin epimerization and procyanidin degradation. Thus, in order to maintain or reduce polyphenol damage within cocoa powder, maximum roasting temperature for the next test is determined at 100,110 and $120^{\circ} \mathrm{C}$.

\subsection{Temperature and Roasting Time in Vacuum Condition on Polyphenol Content of Cocoa Powder}

Polyphenol content has been analyzed since dried 
Table 5 Analysis result of total phenolic and protein in cocoa bean and powder of Lasusua.

\begin{tabular}{lll}
\hline Sample & Total phenolic (\%) & Protein (\%) \\
\hline Dry cocoa beans & 9.94 & 9.30 \\
Cocoa nib & 9.66 & 9.88 \\
Cocoa powder & 9.35 & 10.82 \\
\hline
\end{tabular}

cocoa beans until the form of cocoa powder. Analysis results were shown in Table 5.

Table 5 showed that phenolic percentage in cocoa beans had decreased about $0.59 \%$ during cocoa powder processing. This help in illustrating that preliminary roasting stage, compression and grinding during cocoa powder processing has affected total phenolic reduction. Preliminary roasting in cocoa beans was done to facilitate seed coat peeling in order to gain nib cocoa. This stage could reduce total phenolic percentage as much as $0.28 \%$, but this data also showed that total phenolic reduction during cocoa powder processing is very low.

Subsequently, cocoa powder that uses three level of roasting at 100,110 and $120{ }^{\circ} \mathrm{C}$ was given variation in roasting time that is $25 \mathrm{~min}, 35 \mathrm{~min}$ and $45 \mathrm{~min}$, also vacuum condition consists of $45.6 \mathrm{~cm} \mathrm{Hg}$ and $60.8 \mathrm{~cm}$ $\mathrm{Hg}$ and conventional condition. Total phenolic analysis results at roasting temperature and roasting time (vacuum and conventional) for cocoa powder could be seen in Figs. 5-7.

Based on Fig. 5, it is shown that during $100{ }^{\circ} \mathrm{C}$ roasting with vacuum pressure $45.6 \mathrm{~cm} \mathrm{Hg}$, total phenolic had decreased since the beginning of roasting. This decline continued along with increasing roasting time particularly in min 35 and 45 . While in vacuum roasting of $60.8 \mathrm{~cm} \mathrm{Hg}$ and conventional condition, both showed similar graph pattern in which some increase and decrease of total phenolic was exist. However, increasing and decreasing point of its total phenolic is different according to roasting time. During vacuum roasting of $60.8 \mathrm{~cm} \mathrm{Hg}$, its maximum total phenolic increase exists in min 35, and relatively small in min 25. But after min 35, total phenolic decreased. This graph pattern showed that in the beginning of roasting (vacuum $60.8 \mathrm{~cm} \mathrm{Hg}$ ), there was synthetic process of phenolic compounds, but it degrades after $\min 35$.

Vacuum roasting graph pattern in $110^{\circ} \mathrm{C}$ according to Fig. 6 is very different from graph pattern in $100^{\circ} \mathrm{C}$. In roasting temperature of $110{ }^{\circ} \mathrm{C}$ with vacuum pressure of $45.6 \mathrm{~cm} \mathrm{Hg}$, total phenolic has kept increasing since the beginning of roasting until min 35 . While in roasting temperature of $100^{\circ} \mathrm{C}$, total phenolic has decrease since the beginning until the end of roasting. Different events were also showed in roasting with vacuum pressure of $-60.8 \mathrm{~cm} \mathrm{Hg}$. In $110^{\circ} \mathrm{C}$, total phenolic degraded after roasting time of 25 until 35 min. However, after min 35, total phenolic value is climbing up with value higher than before roasting. Meantime, in $100{ }^{\circ} \mathrm{C}$, total phenolic synthetic was occurring after min 25 until min 35 . But when roasting time was prolonged $10 \mathrm{~min}$, total phenolic degraded.

Raising roasting temperature to become $120{ }^{\circ} \mathrm{C}$ according to Fig. 7 for 25 min would increase total

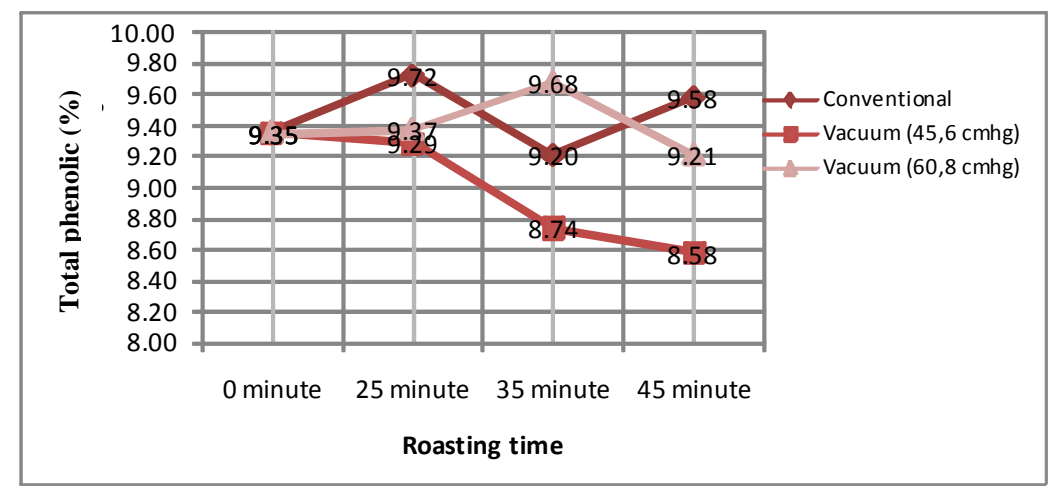

Fig. 4 Effect roasting (vacuum and conventional) cocoa powder at a temperature of $100{ }^{\circ} \mathrm{C}$ to the total phenolic. 

Alteration and Polyphenols Content of Cocoa Powder

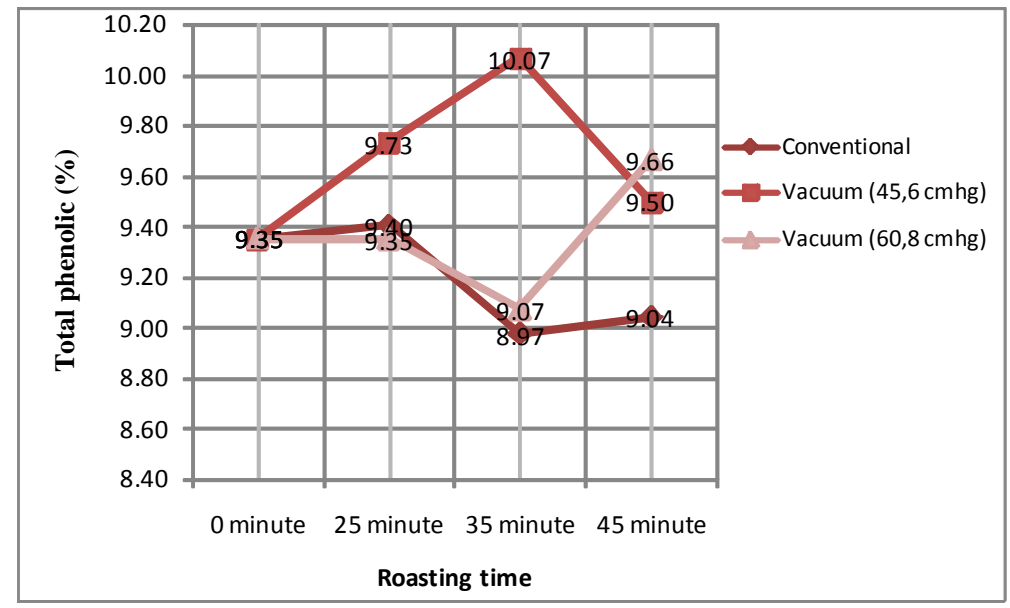

Fig. 5 Effect roasting (vacuum and conventional) cocoa powder at a temperature of $110{ }^{\circ} \mathrm{C}$ to the total phenolic.

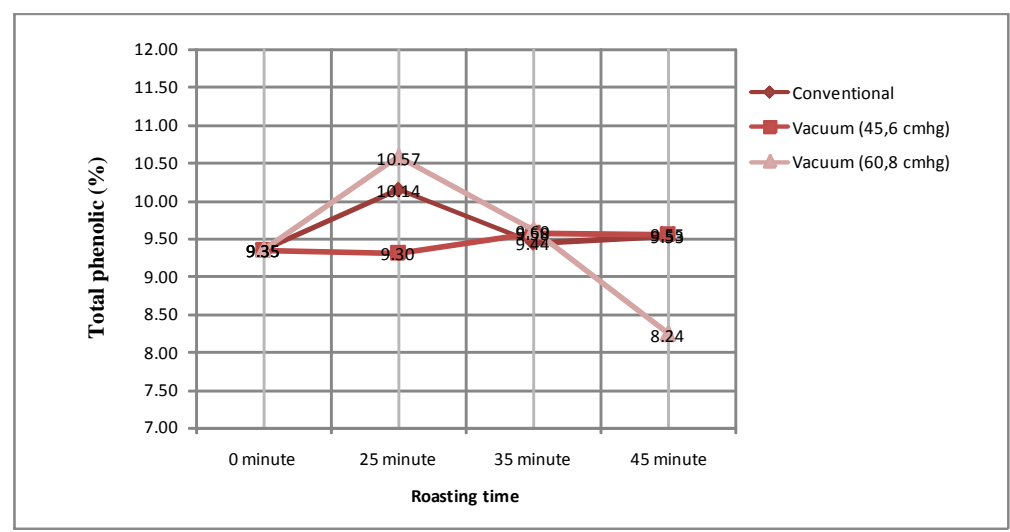

Fig. 6 Effect roasting (vacuum and conventional) cocoa powder at a temperature of $120^{\circ} \mathrm{C}$ to the total phenolic.

phenolic value more than increment at $100{ }^{\circ} \mathrm{C}$ and $110^{\circ} \mathrm{C}$. This condition occurs in vacuum roasting 60.8 $\mathrm{cm} \mathrm{Hg}$ and conventional. However, after passing through 25 min, there was total phenolic degradation. In temperature $120{ }^{\circ} \mathrm{C}$ for 25 min with vacuum pressure $60.8 \mathrm{~cm} \mathrm{Hg}$, it showed the highest value, about $10.57 \%$. But above min 25 until min 45, total phenolic is degraded, therefore its percentage is below the value before roasting or below roasting temperature of $100{ }^{\circ} \mathrm{C}$ and $110^{\circ} \mathrm{C}$.

Other than that, Figs. 6 and 7 also showed that implementation of vacuum roasting could increase total phenolic. Vacuum roasting of $45.6 \mathrm{~cm} \mathrm{Hg}$ in temperature $110{ }^{\circ} \mathrm{C}$ (Fig. 6) with roasting time of 35 min has obtained $10.07 \%$ total phenolic or there is about $0.72 \%$ increase. While in vacuum roasting of $60.8 \mathrm{~cm} \mathrm{Hg}$ in temperature $120{ }^{\circ} \mathrm{C}$ with roasting time $25 \mathrm{~min}$, it is obtained $10.57 \%$ total phenolic, or about
$1.22 \%$ increase. This result might indicate oxygen contribution during roasting process that affecting synthetic and degradation of total phenolic. In vacuum roasting, the amount of oxygen is lower than in conventional roasting. Raising vacuum pressure (60.8 $\mathrm{cm} \mathrm{Hg})$ and temperature $\left(120^{\circ} \mathrm{C}\right)$ were able to improve total phenolic value with shorter processing time (25 $\min )$.

Total phenolic reduction was caused by oxidation process (the existence of oxygen). Supriyanto et al. [20] suggested that during roasting of cocoa beans using EGM (electromagnetic waves) and conventional condition, polyphenol content has altered into smaller value, and it is caused by polyphenol oxidation by oxygen within roasting chamber. Hii et al. [8] suggested that polyphenol reduction in high temperature might be caused by higher redox activity in polyphenol under high level of oxygen. 
Total phenolic reduction might also be caused by interaction with protein. Raw material analysis results in cocoa powder showed that protein level is quite high that is $10.82 \%$ (Table 5). This protein content could interact with polyphenol. Some potential interaction between polyphenol and protein would exist through hydrogen bond, hydrophobic, ionic and covalent bond. Other potential is quinon substances formed from polyphenol oxidation [17, 22, 23].

Quinon substance, at molecular weight above 3,000 could form a complex with protein through hydrogen bond. Or else, it might react with amino acid and protein or other polymer and forming complex with high molecular weight called condensed tannin [23, 24]. Condensed tannin or proanthocyanidin is a polymer with high molecular weight, and its monomer consists of catechin and epicatechin [25].

\section{Conclusions}

Based on the discussion result we might conclude that temperature and vacuum pressure in the roasting chamber could affect color alteration of cocoa powder. Roasting at temperature $100{ }^{\circ} \mathrm{C}, 110{ }^{\circ} \mathrm{C}$ and $120{ }^{\circ} \mathrm{C}$ for 35 min would produce color, aroma and taste of cocoa powder likes by panelist. Furthermore, vacuum roasting was proven could increase total phenolic value. Vacuum roasting at $60.8 \mathrm{~cm} \mathrm{Hg}$ in $120{ }^{\circ} \mathrm{C}$ with roasting time of 25 min would gain the highest total phenolic with $10.57 \%$ and if this roasting time has been prolonged, it would reduce its polyphenol content.

\section{References}

[1] E.S. de Brito, Garcia, N.H.P. Gallão, M.I. Cortelazzo, Structural and chemical change in cocoa (Theobroma cocoa L.) during fermentation, drying and roasting, J. Sci. Food Agric. 81 (2000) 281-288.

[2] T. Wahyudi, T.R. Panggabean dan Pujiyanto, The Complete Guide Cocoa, Agribusiness Management from Upper to Lower, Penebar Swadaya, Jakarta. 2008, p. 363.

[3] B.W. Minifie, Chocolate, Cocoa and Confectionery: Science and Technology, The AVI Publishing Company, INC, Wesport, Connecticut, 1982.

[4] D. Whiting, Natural Phenolic Compounds 1900-2000: A Bird'S Eye View of a Centuries Chemistry, 18th ed., 2001, pp. 583-606.

[5] C.G. Fraga, Cocoa, diabetes and Hypertension: Should We Eat More Chocolate? American J. of Clinical Nutrition, 81 (3) (2005) 541-542.

[6] E. Lecumberri, R. Mateos, M. Izquierdo-Pulido, P. Ruperez, L. Goya, L. Bravo, Dietary fibre composition, antioxidant capacity and physico-chemical properties of a fibre-rich product from cocoa (Theobroma cacao L.), J. Food Chem. 104 (3) (2006) 948-954.

[7] S.M. Hannum, J.W. Erdman, Emerging health benefit from cocoa and chocolate, Journal of Medicine Food 3 (2) (2004) 73-75

[8] C.L. Hii, C.L. Law, M. Cloke, S. Suzannah, Thin layer drying kinetic of cocoa and dried product quality, J. Biosystem Engineering 102 (2009) 153-161.

[9] B.W. Minifie, Chocolate, Cocoa and Confectionery: Science and Technology, The AVI Publishing Company, INC, Wesport, Connecticut, 1982.

[10] A. Othman, A.M.M. Jalil, K.K. Weng, A. Ismail, N. Abd.Gani, I. Adnan, Epicathecin content and antioxidant capacity of cocoa beans from four different countries, African Journal of Biotechnology 9 (7) (2010) 1052-1059.

[11] A. Ruzaidi, A. Maleyki, I. Amin, A.G. Nawalyah, H. Muhajir, M.B.S.M.J. Pauliena, et al., Hypoglycaemic properties of malaysian cocoa (Theobroma cocoa) polyphenol-rich extract, J. International Research Food 15 (3) (2008) 1-8.

[12] A. Chaovanalikit, R.E. Wrolstad, Total Anthocyanins and Total Phenolics of Fresh and Processed Cherries and Their Antioxidant Properties, Journal of Food Science 69 (1) (2004) 67-72.

[13] R. Subhashini, U.S.M. Rao, P. Sumathi, G. Gunalan, A comparative phytochemicals analysis of cocoa and green tea, Indian Journal of Science and Tech. 3 (2) (2010) 188-192.

[14] E.H. Meursing, Cocoa and Chocolate Manual, 40th Anniversary Edition, ADM Cocoa International, Switzerland, 2009.

[15] W. Krysiak, Influence of roasting on coloration of roasted cocoa beans, Journal of Food Enginering 77 (2006) 449-453.

[16] M.W. Davey, V. Montagu, M. Inze, D. Sanmartin, M. Kannellis, A. Smimof, et al., Plant I-ascorbic acid: Chemistry, function, metabolism, bioavalability, and effects of processing, Journal of the Science of Food and Agriculture 80 (2000) 825-860.

[17] M.M.K. Zainol, A. Abdul-Hamid, F. Abubakar, S.P. Dek, Effect of different drying methods on the degradation of selected in centella asiatica, J. International Food Research 16 (2009) 531-537.

[18] G. Ziegleder, B. Biehl, Analysis of cocoa flavour components and flavour precursors, in: H.F. Linskens, J.F. 


\section{Alteration and Polyphenols Content of Cocoa Powder}

Jackson (Eds.), Modern Methods of Plant Analysis, Springer Verlag, Heidelberg, Germany 8 (1998) 323-326.

[19] S. Jinap, B. Jamilah, S. Nazamid, Changes in polyphenol ability to produce astringency during roasting of cocoa liquor, Faculty of Food Science and Biotechnology, UPM Serdang, Selangor, Malaysia, 2004, DOI: www3.interscience.wiley.com/journal.

[20] H. Supriyanto, B. Rahardjo, D.W. Marseno, Changes in temperature, water content, polyphenol content and antioxidative activity cocoa for roasting with microwave energy, J. Agritech. 27 (1) (2007) 18-26.

[21] M. Kofink, M. Papagiannopoulos, R. Galensa, Enantioseparation of catechin and epicatechin in plant food by chiral capillary electrophoresis, Eur. Food Res. Technol. 225 (2007) 569-577.

[22] A. Belščak., D. Komes, D. Horz 'ic', K. Kovačevic', G. D.
Karlovic', Comparative study of commercially available cocoa products in terms, Journal Food Research International 42 (2009) 707-716.

[23] S.S. Noor-Soffalina, S. Jinap, S. Nazamid, S.A.H. Nazimah, Effect of polyphenol and $\mathrm{pH}$ on cocoa mailard-related flavour precursors in $\mathrm{s}$ lipidic model system, Inter. J. of Food Sci. Tech. 44 (2009) 168-180.

[24] Misnawi, Changes in procyanidin and tannin concentration as afected by cocoa liquor roasting, Pelita Perkebunan 25 (2) (2009) 126-140.

[25] Wollgast, E. Anklam, Review on polyphenols in Theoroma cocoa: Changes in composition during the manufacture of chocolateand methodology for indenfication and quantification, Food Research International 33 (2000) 423-447. 